\title{
Performance Assessment of a Hybrid Solar-Geothermal Air Conditioning System for Residential Application: Energy, Exergy, and Sustainability Analysis
}

\author{
Yasser Abbasi, Ehsan Baniasadi, and Hossein Ahmadikia \\ Department of Mechanical Engineering, Faculty of Engineering, University of Isfahan, Hezar Jerib Avenue, \\ Isfahan 81746-73441, Iran \\ Correspondence should be addressed to Ehsan Baniasadi; e.baniasadi@eng.ui.ac.ir
}

Received 4 December 2015; Revised 7 January 2016; Accepted 12 January 2016

Academic Editor: Pouria Ahmadi

Copyright (C) 2016 Yasser Abbasi et al. This is an open access article distributed under the Creative Commons Attribution License, which permits unrestricted use, distribution, and reproduction in any medium, provided the original work is properly cited.

\begin{abstract}
This paper investigates the performance of a ground source heat pump that is coupled with a photovoltaic system to provide cooling and heating demands of a zero-energy residential building. Exergy and sustainability analyses have been conducted to evaluate the exergy destruction rate and SI of different compartments of the hybrid system. The effects of monthly thermal load variations on the performance of the hybrid system are investigated. The hybrid system consists of a vertical ground source heat exchanger, rooftop photovoltaic panels, and a heat pump cycle. Exergetic efficiency of the solar-geothermal heat pump system does not exceed 10 percent, and most exergy destruction takes place in photovoltaic panel, condenser, and evaporator. Although SI of PV system remains constant during a year, SI of GSHP varies depending on cooling and heating mode. The results also show that utilization of this hybrid system can reduce $\mathrm{CO}_{2}$ emissions by almost 70 tons per year.
\end{abstract}

\section{Introduction}

The energy consumption for residential applications is almost one-third of the world's primary energy demand, while it is rapidly increasing due to population growth and improvement in human life standards $[1,2]$. Currently most of the required energy in this sector is supplied by hightemperature sources to meet low-temperature heating needs. These energy crises besides environmental degradation of earth, global warming, and depletion of natural resources have encouraged researchers to investigate the possibility of using environmentally benign energy resources to drive low exergy systems, that is, solar systems, ground source heat exchangers, and so forth, with working temperatures close to environment temperature. Low exergy systems are basically air conditioning systems that utilize low grade energy of sustainable sources to provide heating and cooling effects at a temperature close to room temperature [3].

As a promising approach in energy conservation, heat pumps can be combined with renewable energy sources to provide a low exergy cooling and heating system. Among the renewables, geothermal, wind, and solar are more adoptable to sustainable buildings. Most of the research and developments in renewable energy based systems for residential application are conducted to provide hot water, heating, cooling, and ventilation by heat pumps or vapor-power cycles [4-6]. Ground source heat pumps (GSHP), integrated with certain types of low-temperature distribution system, have been identified as the most efficient and ecofriendly heating and cooling technology for various climates. These systems are energy efficient and they are designed based on the relatively constant temperature of the ground to supply heating during the winter and cooling during the summer. Vertical closed-loop systems are the most efficient, though the most expensive, configuration because the subsoil level of temperature increases and stabilizes with depth [7-9]. Analyses of GSHP have been widely conducted in literature from energetic and exergetic points of view [10-13]. Integration of ground source heat pumps with photovoltaic system is a promising option to supply electricity, hot water, and heating and cooling effects for off-network communities and remote areas [14-16]. 
Combination of different renewable energy sources to meet the demands of a sustainable building is widely studied. Li et al. [17] described a rooftop hybrid heat pump system that uses wind and solar energy to provide hot water, heating, and cooling from energy, exergy, and environmental point of view. Mikati et al. overviewed a small-scale distributed power system that contains photovoltaic arrays, small-scale wind turbines, and an electric grid connection [18]. Dai et al. conducted an experimental study to evaluate the effect of operation modes on the heating performance of a solar assisted ground source heat pump system (SAGSHPS) [19]. Moreover, different concepts of solar assisted heat pump systems with ground heat exchanger are simulated according to IEA SHC Task44/HPP Annex38 reference conditions using TRNSYS software. The dependency of system efficiency on seasonal performance factor and possible shortening of the ground heat exchanger by minimum temperature at the ground heat exchanger inlet are evaluated [20]. The performance of a new system for cooling of solar PV panels called Ground-Coupled Central Panel Cooling System (GCCPCS), which is in operation at the Energy Park of Rajiv Gandhi Proudyogiki Vishwavidyalaya (RGPV), is studied by Sahay et al. [21]. Exergy analysis of photovoltaic system has been conducted broadly. Sobhnamayan et al. [22] have investigated an optimized solar photovoltaic thermal (PV/T) water collector based on exergy concept. Exergy analyses of photovoltaic (PV) and photovoltaic/thermal (PV/T) systems were presented by Saloux et al. [23]. Gholampour et al. [24] have evaluated the performance of the PV/UTC and UTC systems by introducing energy efficiency as a function of electrical-to-thermal ratio number and also the second law efficiency. Exergy and economic evaluation of thermal photovoltaic $(\mathrm{PV} / \mathrm{T})$ water based collectors for different climates in Iran have been conducted by Jahromi et al. [25].

In this study an exergy analysis is conducted to investigate the performance of an integrated PV-GSHP system for space heating and cooling of a remote building. A general arrangement schematic view of the system is illustrated in Figure 1. The required area of SPV panels and GSHP needed length are calculated for the hybrid air conditioning system of a $200 \mathrm{~m}^{2}$ building in a remote area. The effect of different climates on system performance is investigated based on the meteorological data of three cities of Iran (Isfahan, Yazd, and Shahrekord). It is assumed that the building structure is identical for all climate case studies; however the cooling and heating loads, solar irradiation, and ground depth temperature are different. The analysis is based on the monthly averaged energy demands of the building. It is assumed that heat and electricity can be stored during daytime. An energy, exergy, and sustainability analysis is conducted to evaluate the feasibility of utilizing solar assisted ground source heat pump (GSHP) for air conditioning purposes.

\section{System Analysis}

2.1. Heating and Cooling Load. A remote building with $200 \mathrm{~m}^{2}$ area located in Isfahan (elevation: $1590 \mathrm{~m}$ ) is considered to study the performance of an integrated geothermal heat pump and photovoltaic system that provides heating and

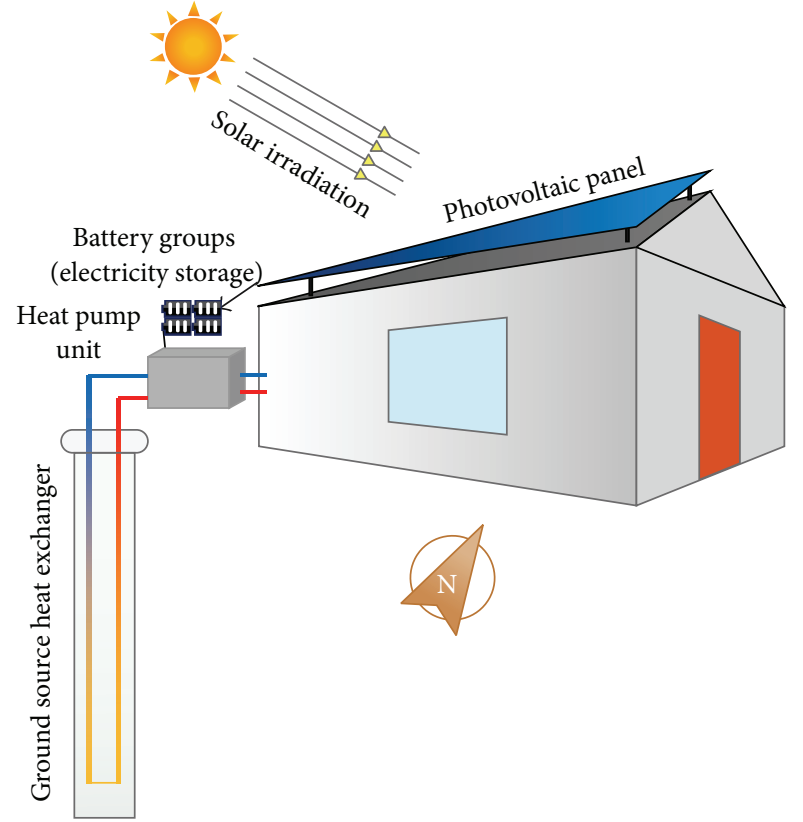

FIGURE 1: Schematic view of the solar assisted GSHP air conditioning system.

cooling loads. The system performances are compared for different cities of Iran including Yazd (elevation: $1216 \mathrm{~m}$ ) and Shahrekord (elevation: $2061 \mathrm{~m}$ ). Figure 1 shows a schematic view of the residential building and the solar assisted geothermal heat pump. The heating, cooling, and hot water demands of the building are calculated based on outdoor design conditions of each city on an hourly basis.

2.2. System Description. Figure 3 shows a flow diagram of the integrated solar assisted GSHP system that operates as an offgrid energy system for the specified residential building. It consists of three main loops.

(1) The ground loop delivers heat energy (in cooling mode) to ground sublayers or takes heat energy (in heating mode) from the ground. A circulating pump circulates water, as a working fluid, in the loop (stream 1). Heat is exchanged with the ground via a network of $n$ number of GSHXs with overall efficiency of $\eta_{g, x}$. The ground temperature $T_{g}$ is almost constant during a year.

(2) The primary loop is basically a Rankin refrigeration cycle that consists of two heat exchangers with exchangeable functions depending on cooling or heating season. In heating mode the first heat exchanger takes heat from the ground loop as an evaporator, while the other heat exchanger delivers heat to the secondary loop as a condenser. In cooling mode the first heat exchanger delivers heat to the ground loop as a condenser and the other extracts heat from the secondary loop as an evaporator. A compressor pressurizes refrigerant R-134a in the primary loop. A 4-way valve is adopted to switch 
cooling and heating mode functions by reversing the refrigerant flow direction.

(3) The secondary loop exchanges heat via a fan-coil heat exchanger with the air conditioned space. A pump is used to circulate water through the loop. The photovoltaic system supplies the required electric power of pumps, compressor, and the fan-coil. This system includes PV panels, convertor, and batteries. The batteries store the generated electricity by the PV system during daytime.

\section{Energy and Exergy Analyses}

The following assumptions are considered for calculating energy and exergy of the streams:

(a) All of the processes are steady.

(b) Potential and kinetic energy of the streams are negligible and no chemical reactions exist.

(c) The compressor mechanical and electrical efficiencies are $80 \%$ and $70 \%$, respectively.

(d) Air is an ideal gas and its specific heat is constant.

(e) The dead state conditions are selected as $T_{0}=10^{\circ} \mathrm{C}$ and $P_{0}=101.325 \mathrm{kPa}$.

(f) The thermodynamic properties of water, air, and R$134 \mathrm{a}$ are calculated using the EES software package.

(g) The mass flow rate calculations are made by EES software.

The case studies are also performed based on the assumptions in Table 1.

3.1. Ground Source Heat Pump. Based on the aforementioned assumptions, mass, energy, and exergy balance equations are applied to find the output power, heat gain, rate of exergy destruction, and energy and exergy efficiencies. The governing equations are as follows [26, 27]:

$$
\begin{aligned}
\frac{d}{d t}\left(M_{\mathrm{CV}}\right)= & \sum_{\text {in }} \dot{m}-\sum_{\text {out }} \dot{m}, \\
\frac{d}{d t}\left(E_{\mathrm{CV}}\right)= & \dot{Q}+\dot{W}+\sum_{\text {in }} \dot{m} h-\sum_{\text {out }} \dot{m} h, \\
\frac{d}{d t}\left(\Phi_{\mathrm{CV}}\right)= & {\left[\sum \dot{Q}_{i}\left(1-\frac{T_{0}}{T_{i}}\right)\right]+\left[\dot{W}+P_{0} \frac{d}{d t}\left(\forall_{\mathrm{CV}}\right)\right] } \\
& +\sum_{\text {in }} \dot{m} \psi-\sum_{\text {out }} \dot{m} \psi-\dot{I}_{\mathrm{CV}},
\end{aligned}
$$

where exergy of any stream $(\psi)$ is defined as

$$
\psi=\left(h-h_{0}\right)-T_{0}\left(s-s_{0}\right)+\frac{V^{2}}{2}+g z .
$$

TABLE 1: Main assumptions for analysis (Isfahan case study, month of January).

\begin{tabular}{lc}
\hline Parameter & Value \\
\hline General parameters & \\
Design temperature & $22.5\left({ }^{\circ} \mathrm{C}\right)$ \\
Dead state temperature & $10\left({ }^{\circ} \mathrm{C}\right)$ \\
Ground temperature & $17\left({ }^{\circ} \mathrm{C}\right)$ \\
Thermal load & $10.1(\mathrm{~kW})$ \\
Solar irradiance & $0.2\left(\mathrm{~kW} \mathrm{~m}{ }^{-2}\right)$ \\
Battery efficiency & $70 \%$ \\
Power conversion efficiency & $18 \%$ \\
\hline GSHX parameters & \\
Working fluid & $\mathrm{Water}$ \\
Inlet temperature & $5\left({ }^{\circ} \mathrm{C}\right)$ \\
Outlet temperature & $15\left({ }^{\circ} \mathrm{C}\right)$ \\
Soil resistance & $230\left(\mathrm{~kW}{ }^{-1} \mathrm{~m}{ }^{\circ} \mathrm{C}\right)$ \\
Ground pump efficiency & $80 \%$ \\
Ground heat exchanger efficiency & $80 \%$ \\
\hline Heat pump parameters & \\
Evaporator pressure & $200(\mathrm{kPa})$ \\
Condenser pressure & $800(\mathrm{kPa})$ \\
Refrigerant & $\mathrm{R}-134 \mathrm{a}$ \\
Condenser efficiency & $80 \%$ \\
Evaporator efficiency & $80 \%$ \\
Compressor efficiency & $80 \%$ \\
Expansion valve efficiency & $80 \%$ \\
\hline Room heater parameters & \\
Working fluid & $\mathrm{Water}$ \\
Onlet temperature & $20\left({ }^{\circ} \mathrm{C}\right)$ \\
Fan-coil heat exchanger efficiency & $30\left({ }^{\circ} \mathrm{C}\right)$ \\
\hline & $80 \%$ \\
\hline & $80 \%$ \\
\hline & \\
\hline &
\end{tabular}

3.1.1. Heat Transfer Process in Fan-Coil. The rate of exergy that is delivered to room due to thermal $\left(\dot{\Phi}_{\text {load }}\right)$ is

$$
\dot{\Phi}_{\text {load }}=\dot{Q}_{\text {load }}\left(1-\frac{T_{0}}{T_{d}}\right),
$$

where $\dot{Q}_{\text {load }}$ is the heating or cooling load of the building and $T_{d}$ is indoor design temperature of the building. The irreversibility rate in the air conditioning heat exchanger is

$$
\dot{I}_{\text {fan-coil }}=\dot{\Phi}_{\text {load }} \pm \dot{m}\left(\psi_{\text {in }}-\psi_{\text {out }}\right) \text {. }
$$

3.1.2. Compression Process. In the hybrid cycle, the input exergy required for compression process, either in pumps or in compressor, is delivered from the photovoltaic system with energy efficiency of 15 percent. By neglecting frictional heating, the rate of irreversibly for compression process is

$$
\dot{I}_{\text {pump }}=\dot{W}_{\text {pump }}+\dot{m}\left(\psi_{\text {in }}-\psi_{\text {out }}\right) \text {. }
$$

The irreversibility due to energy conversion deficiency in electric motors can be written as

$$
\dot{I}_{\text {electric-motor }}=\dot{W}_{\mathrm{PV}}\left(1-\eta_{p, e}\right) \text {. }
$$




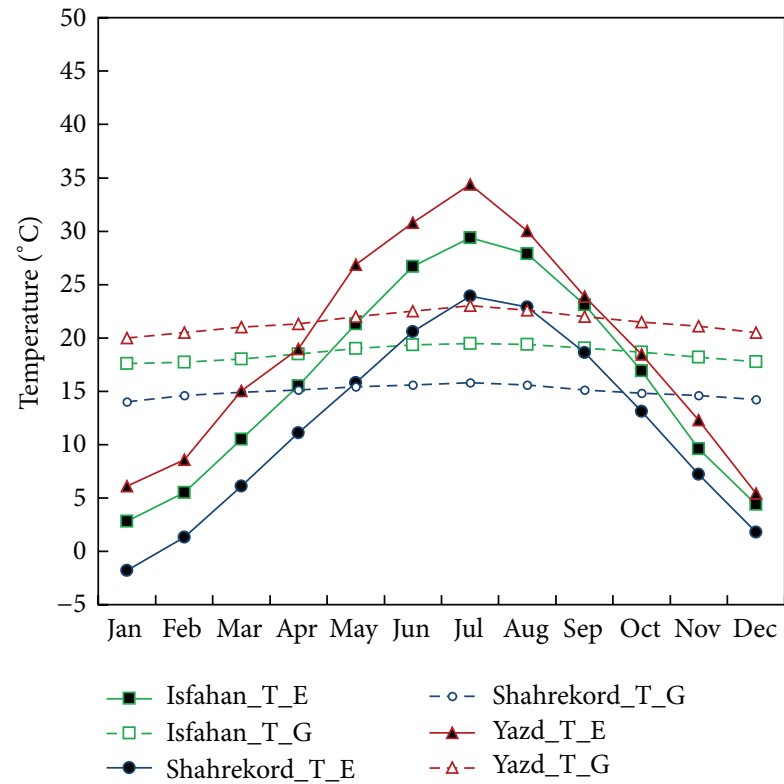

(a)

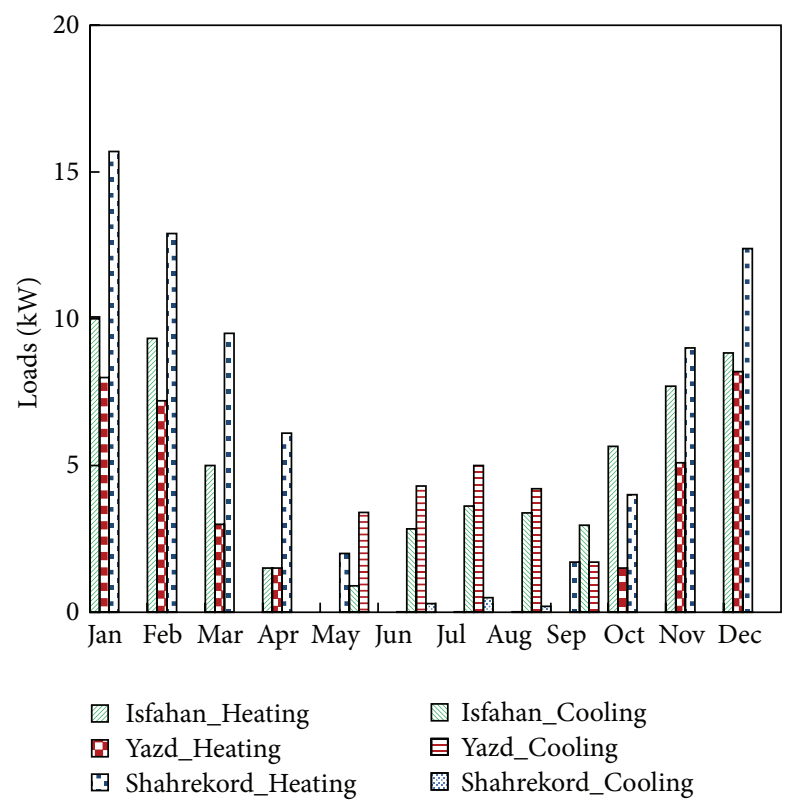

(b)

FIGURE 2: Monthly variations of environment and ground temperature for different cities (a) and corresponding cooling and heating loads calculated with available software (b).

3.1.3. Evaporator and Condenser. Exergy balance for this process is given by

$$
\dot{I}_{\mathrm{CV}}=\sum_{\text {in }} \dot{m} \psi-\sum_{\text {out }} \dot{m} \psi
$$

Thus evaporator or condenser lost exergy is

$$
\dot{I}_{e, c}=\left(\dot{m}_{1} \psi_{1, \text { in }}+\dot{m}_{2} \psi_{2, \text { in }}\right)-\left(\dot{m}_{1} \psi_{1, \text { out }}+\dot{m}_{2} \psi_{2, \text { out }}\right) .
$$

3.1.4. Throttling Process. The exergy loss rate $\dot{I}_{\mathrm{CV}}$ in the throttling valve is

$$
\dot{I}_{\text {tr }}=\dot{m}\left(\psi_{\text {in }}-\psi_{\text {out }}\right) .
$$

3.1.5. Ground Source Heat Exchanger. The exergy rate that is extracted from ground $\dot{\Phi}_{\text {geo }}$ is

$$
\dot{\Phi}_{\text {geo }}=\dot{Q}_{\text {geo }}\left(1-\frac{T_{0}}{T_{\text {geo }}}\right),
$$

where $\dot{Q}_{\text {geo }}$ is the exchanged heat between the ground and the working fluid in the heat exchanger loop and $T_{\text {geo }}$ is the average ground temperature in a specific depth.

The ground temperature $T_{\text {geo }}$ is a function of several parameters. It can be calculated using the following equation:

$$
T_{\text {geo }}=T_{\text {mean }}+A^{\prime} \cos \left(\omega\left(t-t_{0}\right)-\frac{z}{d}\right) \times e^{-z / d}
$$

where $T_{\text {mean }}$ is annual average temperature $\left({ }^{\circ} \mathrm{C}\right), A^{\prime}$ is temperature wave magnitude $\left({ }^{\circ} \mathrm{C}\right), \omega$ is temperature wave frequency $[2 \pi /(365 \times 24$ hours $)], t_{0}$ is time for the warmest day of a year (hour), $z$ is ground depth (m), and $d=\sqrt{2 \alpha / \omega}$, in which $\alpha$ is heat conductivity of soil ( $\mathrm{m}^{2} /$ hour).

The pipe length of GSHX is calculated by

$$
L_{\mathrm{GSHX}}=\frac{\dot{Q}_{\mathrm{geo}}}{T_{\mathrm{geo}}-\bar{T}_{W, G}} \frac{1}{R_{\mathrm{tot}}},
$$

where $R_{\text {tot }}$ is the total thermal resistance of soil, pipe, and water and $\bar{T}_{W, G}$ is the mean temperature of water flowing through ground source heat exchanger. Considering physical properties of polyethylene pipe, soil, and water the total thermal resistance is $R_{\text {tot }} \approx 230 \mathrm{~kW} / \mathrm{m}^{\circ} \mathrm{C}$.

The exergy destruction rate in the heat transfer process is

$$
\dot{I}_{\mathrm{GSHX}}=\dot{\Phi}_{\text {geo }}+\dot{m}\left(\psi_{\text {in }}-\psi_{\text {out }}\right) .
$$

3.2. Photovoltaic System. Solar Irradiance is a measure of how much solar power can be delivered at a specific location. Figure 4 illustrates the monthly solar irradiation averaged over 22 years for different cities. Figure 4 provides the information on the available solar irradiation in case of using PV panel with sun tracking, based on [28]. This information is then used to calculate the average daily power generation from the photovoltaic system in each month.

The actual energy input from solar radiation may be defined as below [23]:

$$
\dot{W}_{\text {solar }}=A I_{s}
$$

where $I_{s}$ is solar irradiance intensity and is $A$ photovoltaic panel net area. 


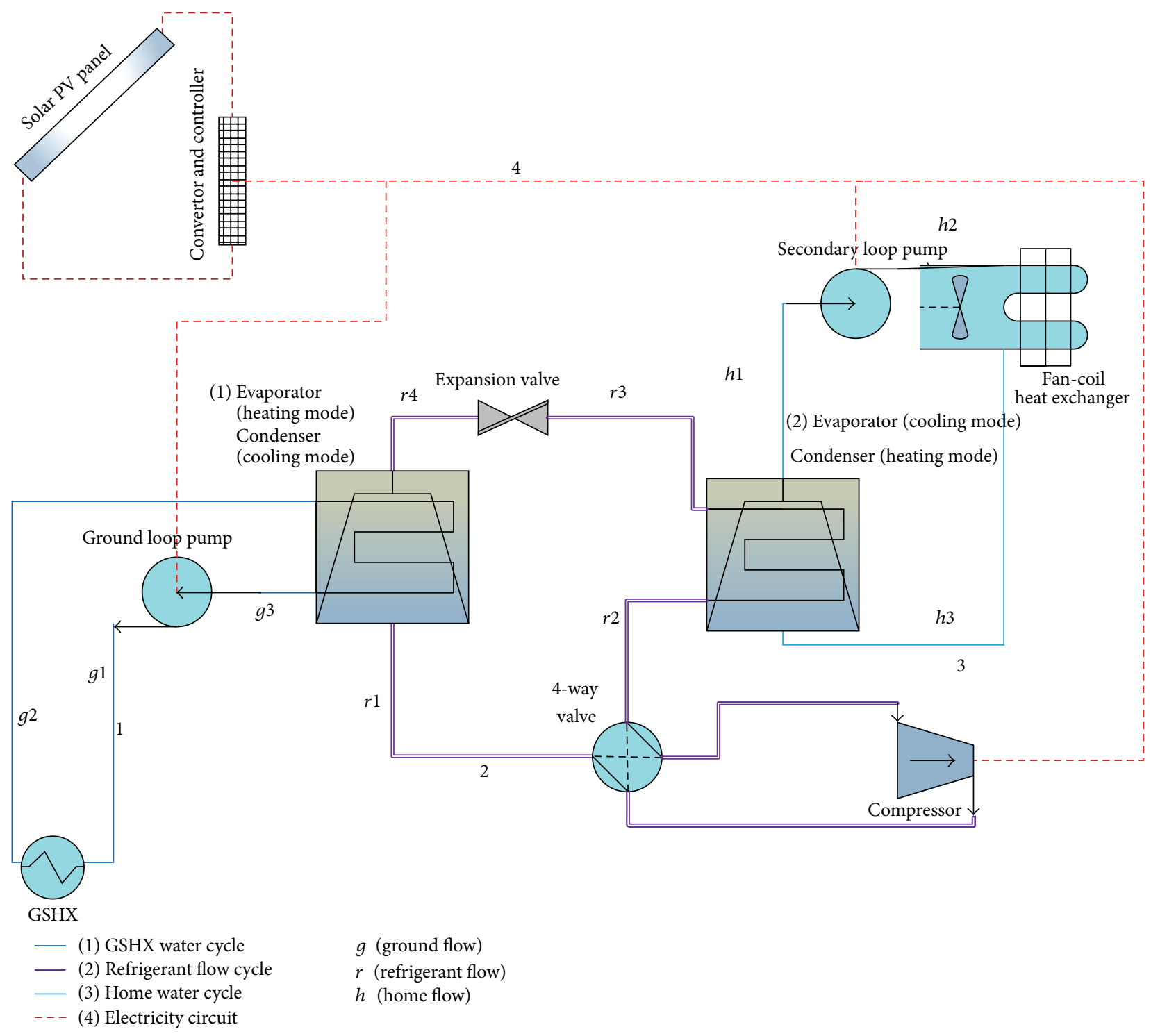

FIGURE 3: Flow diagram of the integrated solar assisted GSHP system.

The input exergy of solar radiation is given by [29]

$$
\dot{\Phi}_{\mathrm{in}, \mathrm{solar}}=\left(1-\frac{4}{3}\left(\frac{T_{0}}{T_{s}}\right)+\frac{1}{3}\left(\frac{T_{0}}{T_{s}}\right)^{4}\right) I_{s} A,
$$

where $T_{s}$ is the sun temperature and is taken as $5777 \mathrm{~K}$. The exergy balance for the PV module can be written to find the associated irreversibility as follows [30-32]:

$$
\dot{\Phi}_{\mathrm{in}, \text { solar }}=\dot{W}_{\mathrm{PV}}+\dot{I}_{\mathrm{PV}}
$$

It is shown that PV output exergy can be calculated as

$$
\dot{W}_{\mathrm{PV}}=V_{m} I_{m}
$$

where $V_{m}$ is PV voltage and $I_{m}$ is generated current.
The energy conversion efficiency of PV module can be defined as the ratio of the net electrical output power to the input energy as below:

$$
\eta_{\text {pce }}=\frac{V_{m} I_{m}}{I_{s} A}
$$

3.3. Overall System Analysis. The input exergy to the hybrid cycle is received from the geothermal source $\left(\Phi_{\text {geo }}\right)$ and photovoltaic system $\left(\Phi_{\mathrm{PV}}\right)$. The desired exergy that is delivered to the house is $\Phi_{\text {load }}$. Therefore, the second low efficiency for the hybrid cycle is

$$
\eta_{\mathrm{II}}=\frac{\dot{\Phi}_{\text {load }}}{\dot{\Phi}_{\text {geo }}+\dot{\Phi}_{\mathrm{PV}}} .
$$




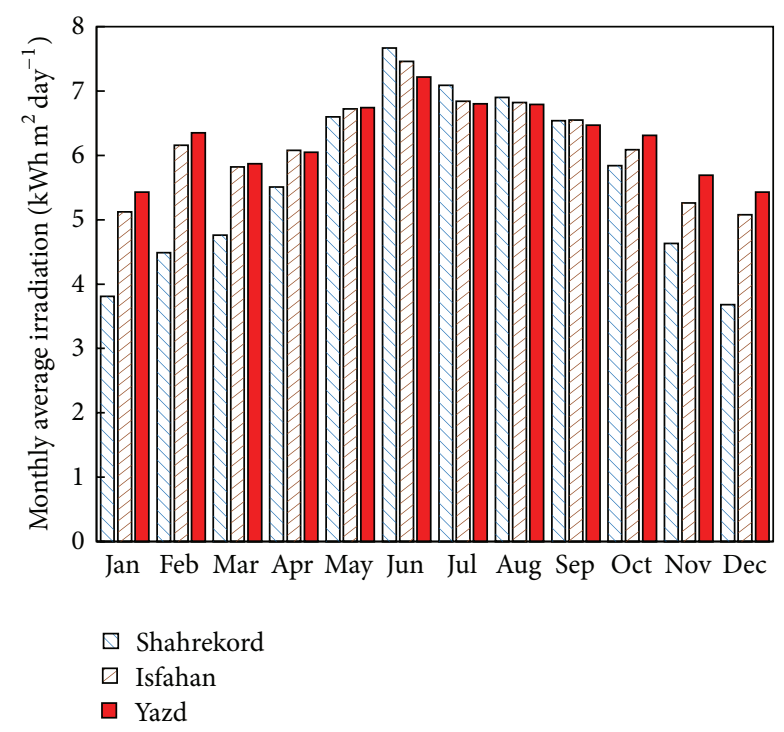

FIgURE 4: Monthly average solar irradiation for different cities.

Total exergy losses are calculated by

$$
\begin{aligned}
\dot{I}_{\text {total }}= & \dot{I}_{\mathrm{GSHX}}+\dot{I}_{\text {evaporator }}+\dot{I}_{\text {condenser }}+\dot{I}_{\text {tr }} \\
& +\sum\left(\dot{I}_{\text {pump }}+\dot{I}_{\text {electric-motor }}\right) .
\end{aligned}
$$

3.4. Sustainability Analysis. Exergy analysis can be further extended to investigate the sustainability of the cycle, either at design stage or for the existing condition. The sustainability index gives useful information about how exergy efficiency of subsystems affects the sustainability of the energy resources and overall system. Higher sustainability index indicates more sustainability of the process or system. The sustainability index (SI) is defined as [29]

$$
\mathrm{SI}=\frac{1}{1-\Psi}
$$

where

$$
\Psi=\frac{\text { output exergy }}{\text { input exergy }}
$$

It is also useful to investigate the performance of the subsystems using relative irreversibility (RI), that is, the ratio of the subsystem exergy destruction rate $\dot{I}_{s}$ to the overall system exergy destruction rate $\dot{I}_{\text {tot }}$ :

$$
\mathrm{RI}=\frac{\dot{I}_{s}}{\dot{I}_{\text {tot }}}
$$

\section{Results and Discussions}

4.1. Exergy Flow Diagram. Figure 5 illustrates a Grassmann diagram of the hybrid system. The flow of exergy from energy sources, for example, solar and geothermal energy, useful exergy delivered to building, and exergy destruction are shown, quantitatively. The results are related based on Isfahan climate in January. It can be concluded that most exergy destruction takes place in photovoltaic modules. Around $82 \%$ of the total incident solar exergy is captured by the photovoltaic system, of which about $76 \%$ is destroyed due to energy conversion deficiencies of the PV panels. From $24 \%$ of the input solar exergy that is delivered to the battery storage, compressor, and pumps, about $15 \%$ is destructed due to irreversibility in these components as well as ACDC converter. Therefore, almost $10 \%$ of solar irradiance exergy would be converted to useful work in the pumps and compressor. Improvement in energy conversion efficiency of the mechanical and electrical equipment's and heat exchanger redesign can avoid exergy losses to some extent. On the other hand, about $67 \%$ of the total input exergy from GSHP system that is delivered to the evaporator, condenser, and other heat exchangers is lost due to irreversibility in heat transfer processes.

4.2. Exergy Efficiency. The variation of exergy efficiency of the system during a year is illustrated in Figure 6. The exergy efficiency of the hybrid cycle is almost constant during the hot season and it is at its lowest value of $2 \%$. During the cold season, however, the efficiency of the system would increase. The exergy efficiency is highly dependent on the GSHP performance. During hot seasons, ground temperature and ambient temperature are more close to each other compared to the cold season. It will cause low geothermal exergy input during the hot season. Although, during cold seasons, cooling mode and ambient temperature are so variable (in comparison to the hot season), ground temperature remains nearly constant. This fact causes a variable geothermal exergy input in cold seasons. As solar exergy is relatively less variable during cold seasons, exergy efficiency of the system is highly dependent on geothermal subsystem exergy efficiency. On the other hand, the highest exergy efficiency values are for the coldest season of Jan and Dec. During these seasons, the geothermal system has a better performance because of the highest difference between ground depth temperature and ambient temperature in cold seasons.

4.3. Sustainability and Relative Irreversibility Analysis. Figures 7 and 8 represent the sustainability index of the two main energy harvesting compartments, namely, photovoltaic and geothermal systems, as well as the integrated cycle. As exergy input from the solar system is far greater than the geothermal system (due to extensive destruction of PV system) sustainability index of the integrated system is relatively constant as the solar system. It can be observed from Figure 7 that PV system sustainability has limited dependency on dead state temperature. It can be also concluded from (15) that the difference between temperature of the sun and dead state temperature compensates the effect of this parameter on the input exergy from the sun to the PV system. As shown in Figure 8 , the PV system sustainability index is 1.2 during a year. On the other hand, the sustainability index of GSHP system is a function of dead state temperature. Since in this study the ground temperature is taken as $17^{\circ} \mathrm{C}$, the GSHP sustainability index is minimum when dead state temperature 


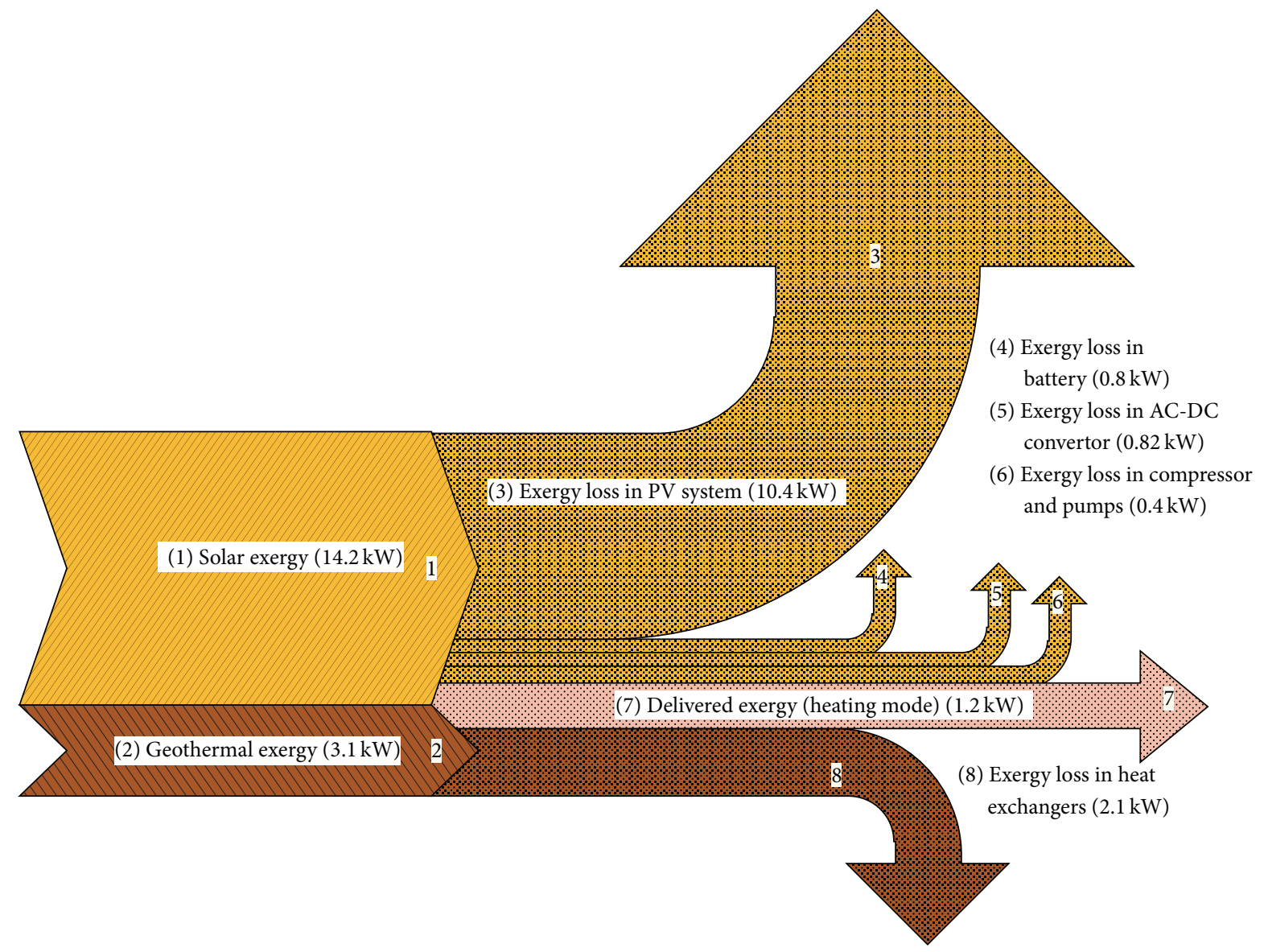

FIGURE 5: Grassmann diagram for hybrid cycle in heating mode (without scale).

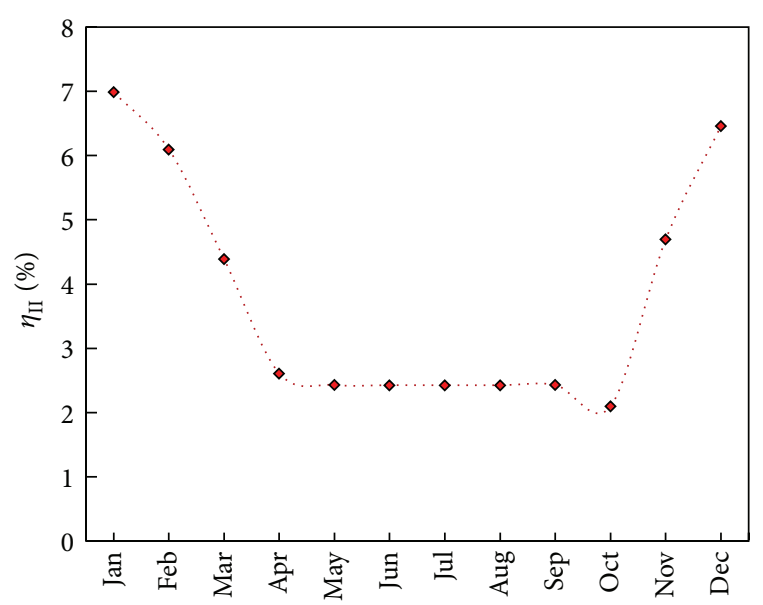

FIGURE 6: Exergy efficiency of integrated SPV and GSHP for different months.

is $15^{\circ} \mathrm{C}$. Sustainability index of GSHP will be constant during the hot season (cooling mode) because the design indoor temperature and ground temperature are close to each other and ambient temperature changes are limited. During the cold season, as the ambient temperature decreases the sustainability of GSHP increases. It shows that the hybrid cycle

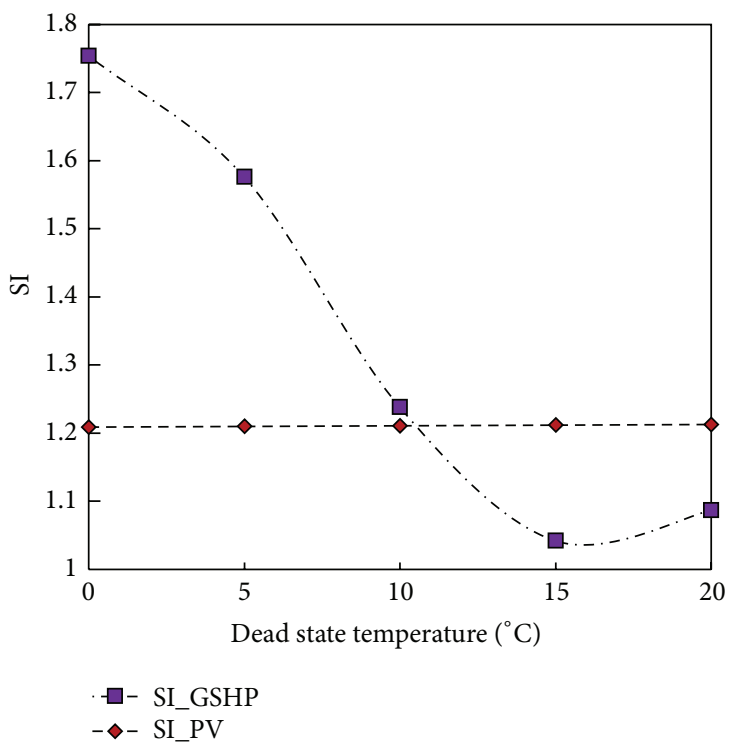

FIGURE 7: Sustainability index of the GSHP and PV systems versus dead state temperature.

is more sustainable, and exergy destruction is lower in the cold season. However, during April and October months due to the close environment temperature to the indoor design 


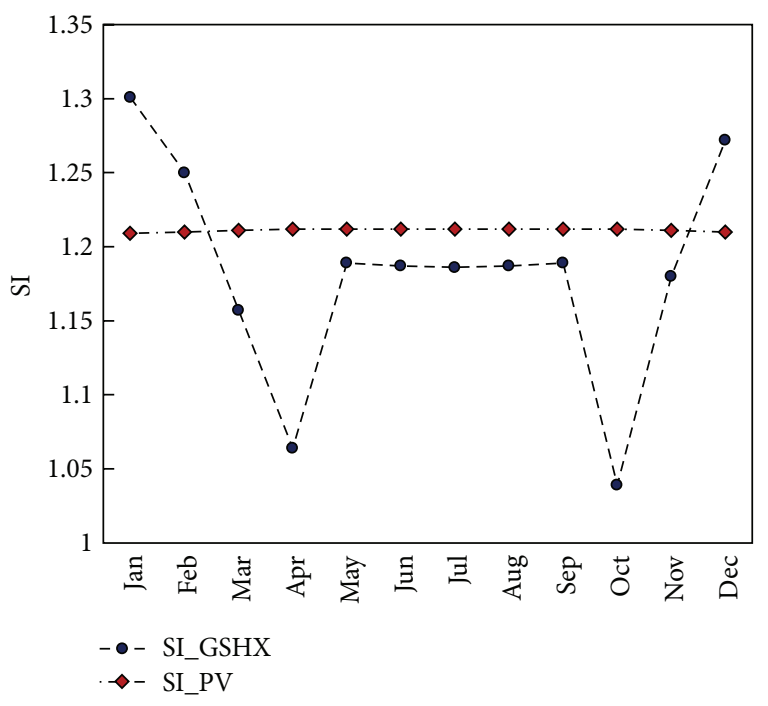

FIGURE 8: Sustainability index of the GSHP and PV systems during a year.

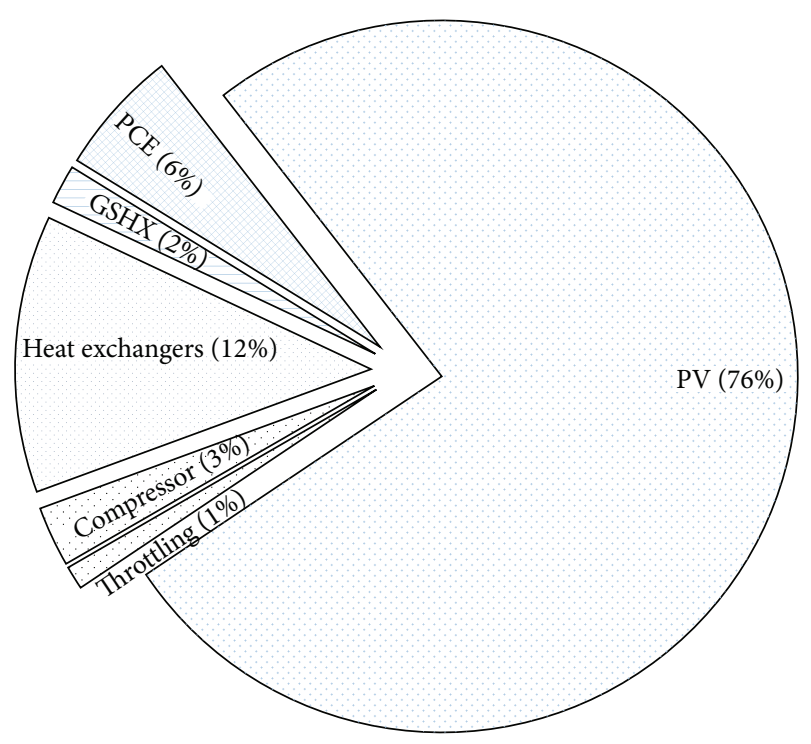

FIGURE 9: Relative irreversibility of components.

temperature, the cooling and heating loads are much smaller than the cycle capacity and the output exergy decreases significantly comparing with input exergy. In fact, the hybrid cycle irreversibility's and exergy destruction increase and its sustainability index are of minimum value during these months.

Figures 9 and 10 illustrate the relative irreversibility of the units/process for the entire cycle and the GSHP subsystem, respectively. It is shown in Figure 9 that most exergy destruction takes place in the PV system. The photovoltaic cells, AC-DC converter, and battery system destruct about $82 \%$ of overall input exergy (I_PV + I_PCE). The next most exergy destructive process is related to heat exchange in evaporator and condenser. These two processes destruct almost $12 \%$ of the total input exergy. Figure 10 indicates that about $70 \%$ of

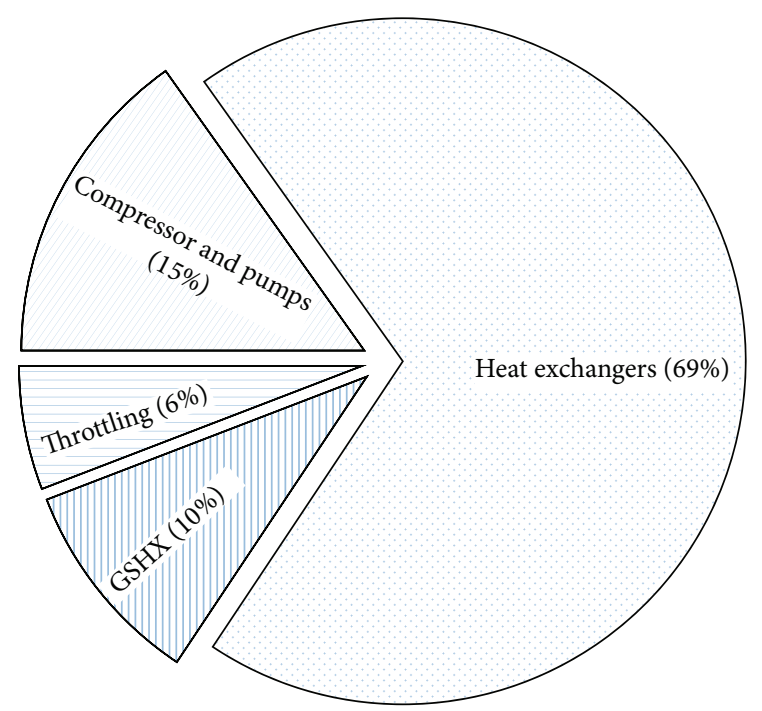

FIGURE 10: Relative irreversibility of GSHP components.

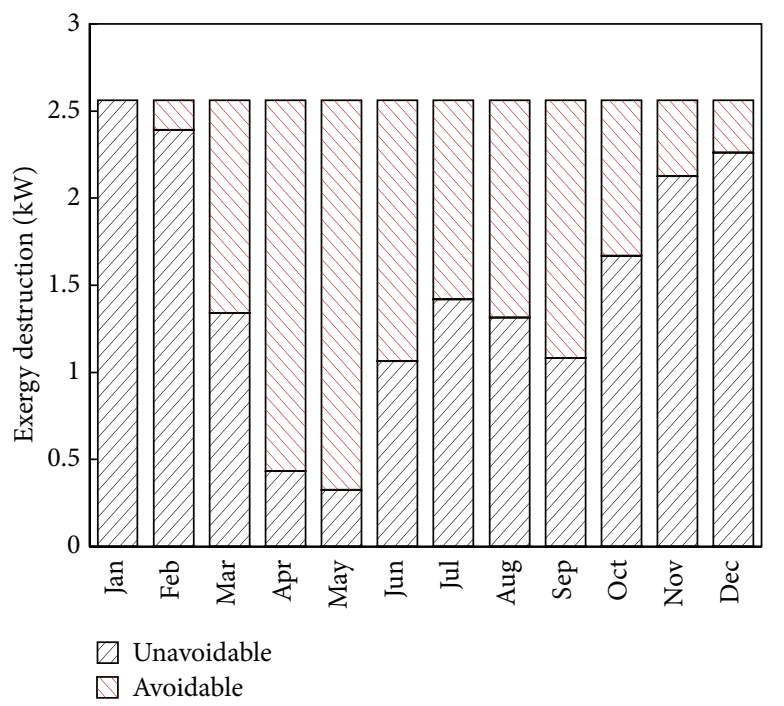

FIGURE 11: Exergy destruction rate of GSHP system during a year.

the exergy destruction in GSHP is due to heat exchange in condenser and evaporator.

4.4. Design Constraint Effects. The main design constraints of the hybrid cycle are the length of ground source heat exchanger and the PV panel's area. Any design criteria for these parameters can change the exergy analysis results. Climate characteristics can also affect the performance of the system. The COP of the system is a function of refrigeration mass flow rate as well. Therefore to reflect the effect of the aforementioned design constraints on the performance of the hybrid cycle from the second law of the thermodynamic point of view, the results are extended as shown in Figures 11-17. The effects of different climates on the performance of the systems are compared in different case scenarios as shown in Figures 16 and 17. 


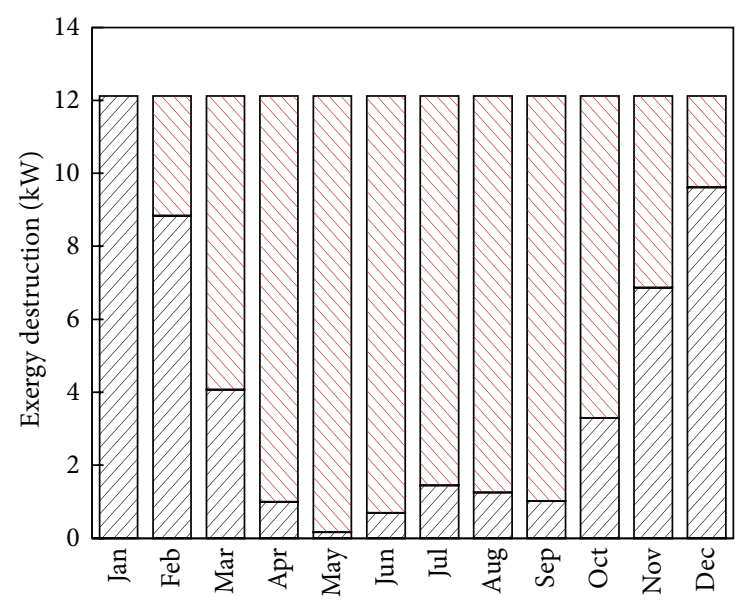

$\square$ Unavoidable

$\square$ Avoidable

FIgURE 12: Exergy destruction rate of PV system during a year.

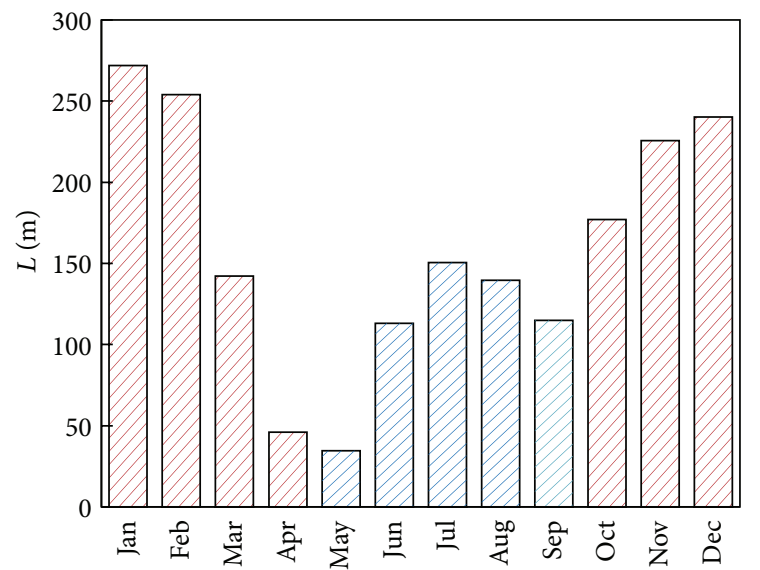

FIGURE 13: GSHX minimum required length for each month.

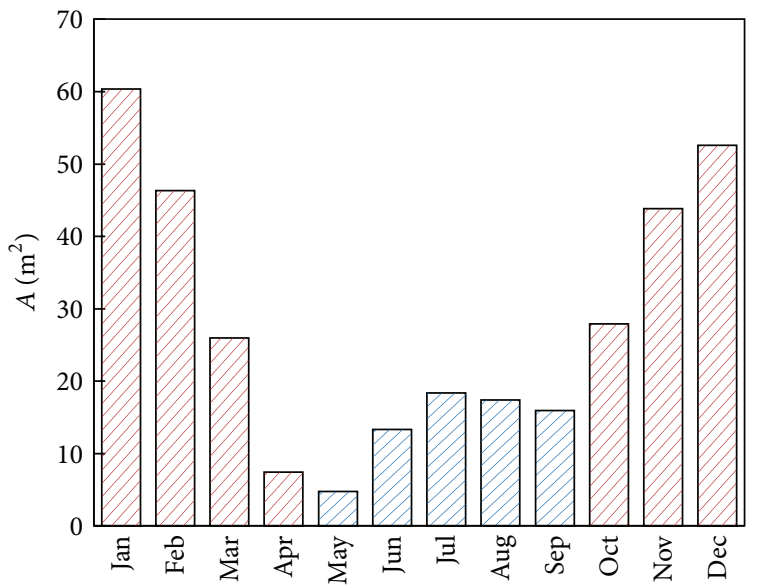

Figure 14: PV panel minimum required area for each month.

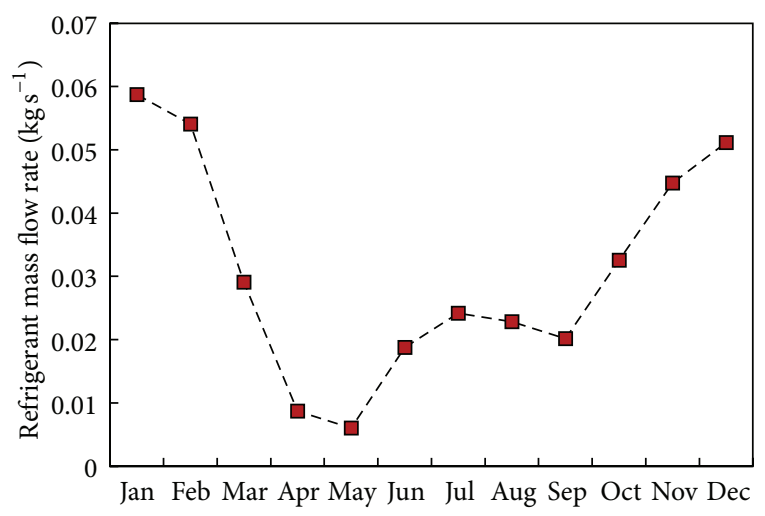

FIGURE 15: Heat pump refrigerant mass flow rate variation.

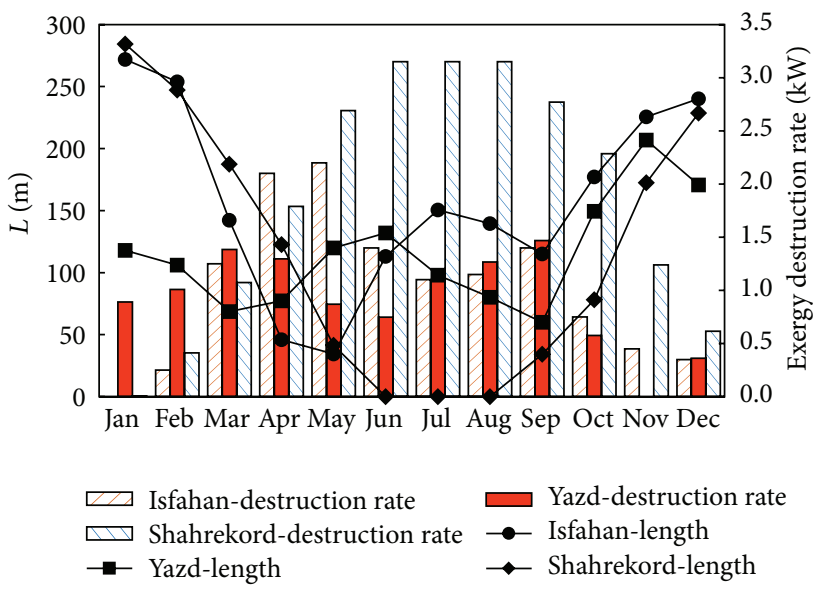

FIgURE 16: Monthly GSHX minimum required length and system exergy destruction rate.

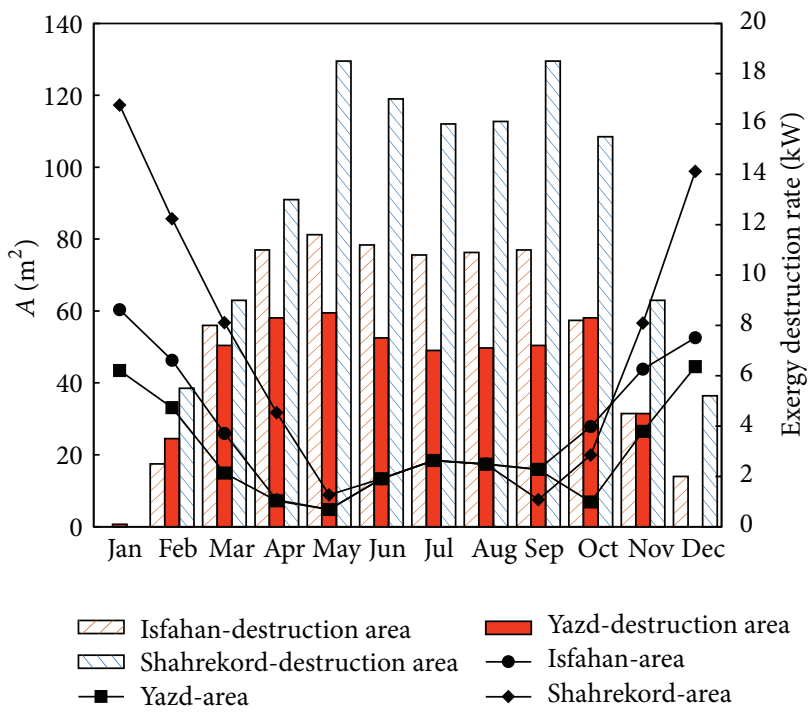

FIGURE 17: Monthly PV panel minimum required area and system exergy destruction rate. 
Figures 11 and 12 present the exergy destruction rate of GSHP and PV system during a year based on the minimum required GSHX length and PV panel area, respectively. The exergy destruction rate of the entire cycle can be divided into two unavoidable and avoidable parts. The unavoidable part refers to exergy destruction due to irreversibility of different applicable process that takes place within the hybrid cycle with the minimum required sizes of the compartments, and the other part is related to overdesign condition of the system in different months. In other words, unavoidable exergy destruction is due to internal irreversibility of component; however, the avoidable exergy destruction is due to overdesign of system such as excessive photovoltaic area or GSHX length. An air conditioning system for a specific building is usually designed for the extreme climate conditions, for example, the hottest and coldest day of a year, and control systems are considered to minimize energy consumption for the rest of the year. However, in case of using solar and geothermal systems, the length of heat exchangers and the area of PV panels only match with the maximum energy demand and it leads to excess input exergy loss during most of the days of operation. It is observed that exergy loss due to input and demand exergy mismatch is much higher in the PV system comparing with GSHP system. Excess available energy can be stored for system operation during either night or peak hours. In fact, the design of the entire cycle can be optimized based on the average energy demand and energy storage systems can be used to compensate for the peak energy consumption conditions. As it is shown in Figures 12 and 14, during the hot season a considerable portion of the solar PV panels is not utilized. Maximum exergy destruction rate occurs in May due to mismatch between system size and building energy demands. The cooling and heating loads at this month are minimum with amount of about $14 \mathrm{~kW}$. Almost $12 \mathrm{~kW}$ of destructed exergy at this month is avoidable by energy storage in battery.

The variation of heat pump refrigerant flow rate based on the climate changes during a year is illustrated in Figure 15. It can be concluded that, for the city of Isfahan during the cold months of winter, when both PV panel's area and GSHX length are maximum, high refrigerant flow rates are also required. In fact high energy demand and low solar irradiation during these months lead to considerable almost 2 times increase in irreversibility. This irreversibility mostly occurs in heat exchangers of the hybrid cycle.

4.4.1. Effect of Climate Changes on System Performance. In order to investigate the performance of the hybrid cycle in different climates, the calculations are repeated for two more cities with different weather conditions. The hybrid cycle is designed to supply the maximum and heating and cooling loads during a year. Isfahan city has warm summers and cold winters, Shahrekord city has quite cold winters and mild summers, and Yazd city has very hot summers and mild winters. Ground temperature, weather data, and solar irradiance for the three different cities are obtained via local meteorological data. Variation of the required length of GSHX during a year is more uniform for Yazd city, but the required PV panel area varies considerably. Figures 16 and 17 compare the exergy

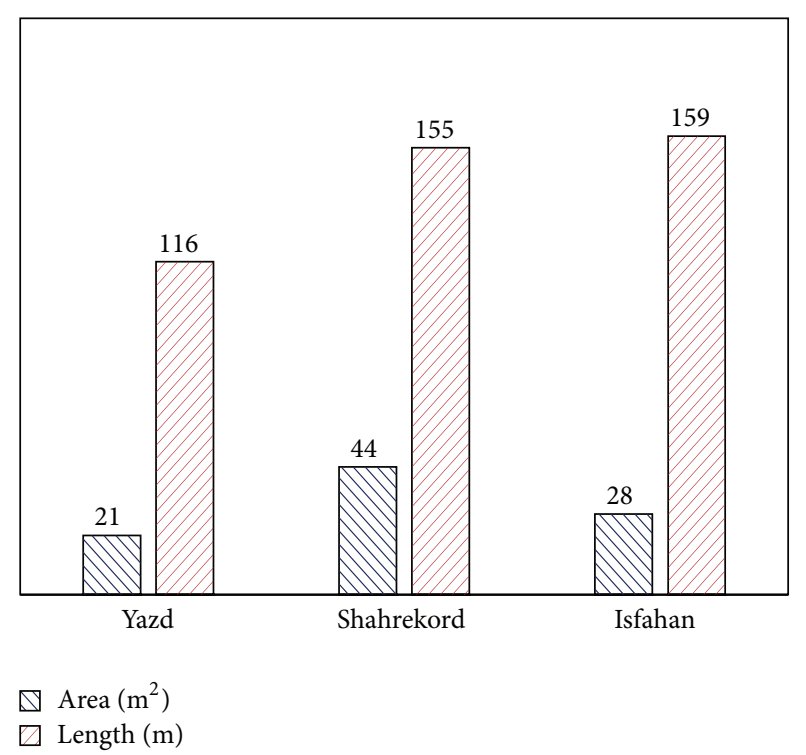

FIGURE 18: Average required PV area and GSHX length.

destruction rates of the hybrid cycle in the three cities. It can be concluded that both GSHX and PV systems have the largest exergy destruction rate in Shahrekord city due to considerable changes of the atmosphere average temperature during a year and also dimensional mismatch between the required and available sizes of GSHX and PV. The building in Shahrekord city has much lower cooling load than heating load, whereas the situation is vice versa in Yazd city. Therefore different arrangements to avoid exergy destruction can be made in these two cities. In other words, energy storage systems and control systems may be applied based on the hybrid cycle performance in each city individually. The results show that the hybrid cycle has almost two times lower exergy destruction rate during the cold season comparing with the hot season. Although the design of GSHX and PV systems is based on the maximum heating and cooling loads, excess absorbed energy can be saved in battery or prevented using a bypass valve in case of ground source heat exchangers.

In another approach, the hybrid cycle can be designed based on the average energy demands of the building during a year. Consequently, the GSHX and PV sizes are reduced and the exergy destruction due to mismatch of the system size and energy demands can be minimized. The capital investment of the system is also reduced considerably. Since the hybrid cycle, in this case, cannot supply the energy demands of the building in some months, the grid electricity may compensate for the required loads. Figure 18 shows the average solar PV panel area and GSHX length for 3 different climates that can be considered for redesigning the cycle; however it might not be the optimum solution as the exergy efficiency and the investment cost should be simultaneously optimized in a detailed study.

4.5. Environmental Benefits. The hybrid GSHP-PV cycle can be utilized to supply the total or part of the building energy demand that leads to considerable decreases in $\mathrm{CO}_{2}$ 
emissions. Based on the cooling and heating energy demands of the building that is located in Isfahan, as shown in Figure 2, the annual energy consumption (AEC) would be approximately $60000 \mathrm{kWh}$ per year. Based on the lower heating value $(\mathrm{LHV}=47.174 \mathrm{MJ} / \mathrm{kg})$ of natural gas and 40 percent energy conversion efficiency $(\eta=40 \%)$ in power plants, almost $20000 \mathrm{~m}^{3}$ of methane will be saved according to (24). Equivalent carbon dioxide emission is calculated by (25). In this equation $E_{c}$ is specific carbon dioxide emissions of natural gas. Based on (25) (with $E_{c}=0.2$ ) reduction of about $1.2 \times 10^{4} \mathrm{~kg}$ carbon dioxide emission is achieved annually $[22,33]$. If the hybrid cycle is designed based on the average required area and length of PV and GSHX, the annual carbon dioxide emission reduction is almost $0.85 \times 10^{4} \mathrm{~kg}$ :

$$
\begin{aligned}
& \forall=3.6(\mathrm{Mj} / \mathrm{kWh}) \times \frac{\mathrm{AEC}}{(\rho \times \eta \times \mathrm{LHV})}, \\
& m=E_{c} \times \text { AEC. }
\end{aligned}
$$

\section{Conclusion}

The performance of a hybrid solar-geothermal air conditioning system is investigated to provide the cooling and heating energy demands of a residential building. Utilization of green sources of energy results in low exergy efficiency of about 10 percent, since solar and geothermal energy conversion facilities are considerably exergy destructive. However considerable saving in fossil fuels and reduction in green house effects are observed. The hybrid cycle performance in different climates is evaluated, and it is observed that the exergy destruction due to mismatch of the area of solar panels and length of ground source heat exchanger with energy demands in each month is less in climates with very hot summer and mild winter. The sustainability index of the ground source heat pump systems greatly depends on the dead state temperature whereas the PV system does not. Almost 76 percent of the exergy destruction in the hybrid cycle is due to inefficiencies of the PV system and about 70 percent of irreversibility in GSHP system occurs in the heat exchangers. The following conclusions are made in this study:

(i) The hybrid system has higher exergy efficiency during the cold season.

(ii) In the hybrid system, exergy destruction mostly takes place in photovoltaic modules.

(iii) The photovoltaic cells, AC-DC converter, and battery system destruct about $82 \%$ of overall input exergy.

(iv) About $76 \%$ of PV panel input exergy is destroyed due to energy conversion deficiencies of the PV panels.

(v) Exergy loss due to mismatch of input and demand exergy is much higher in the PV system comparing with the GSHP system.

(vi) In the GSHP system, most exergy destruction takes place in heat exchangers.

(vii) Geothermal system has a better performance during the cold season, because of the highest difference between ground depth temperature and ambient temperature.

(viii) The PV system sustainability index is 1.2 during a year, but the sustainability index of GSHP system is a function of dead state temperature.

(ix) The hybrid system is more sustainable during the cold season.

(x) If the hybrid cycle is designed based on the average energy demands of the building during a year, the GSHX and PV sizes are reduced and the exergy destruction due to mismatch of the system size and energy demands can be minimized.

(xi) If the cycle is designed based on the average required area and length of PV and GSHX the annual carbon dioxide emission reduction is almost $5 \times 10^{4} \mathrm{~kg}$.

The evaluation of the hybrid system (GSHP coupled with PV panel) for different cities (with different climates) results in the following conclusions:

(i) Both GSHX and PV systems have the largest exergy destruction rate in Shahrekord city (the coldest climate) due to considerable changes of the atmosphere average temperature during a year and also dimensional mismatch between the required and available sizes of GSHX and PV.

(ii) Different arrangements to avoid exergy destruction can be made in Shahrekord and Yazd.

Although coupling the GSHX and PV systems causes considerable exergy destruction (especially during the cold season), the hybrid system is capable of providing a clean source of district cooling and heating for regions with limited access to power grid. It is suggested that more study be conducted in order to evaluate primary and secondary cost (exergoeconomical aspect). The optimum design of the GSHX-PV system can be identified using exergoeconomic analysis that is undertaken as the continuation of this study.

\section{Nomenclatures}

\section{Variables}

A: $\quad$ Photovoltaic panels area $\left(\mathrm{m}^{2}\right)$

AEC: Annual energy consumption (kWh)

$A^{\prime}$ : $\quad$ Temperature wave magnitude (K)

$d: \quad$ Depth parameter $(\mathrm{m})$

E: $\quad$ Energy (kJ)

$E_{c}: \quad$ Specific carbon dioxide emissions

$h$ : $\quad$ Enthalpy per unit of mass $\left(\mathrm{kJ} \mathrm{kg}^{-1}\right)$

I: $\quad$ Irradiance intensity $\left(\mathrm{kJ} \mathrm{m}^{-2}\right)$

$\dot{I}: \quad$ Irreversibility (destruction) rate $\left(\mathrm{kJ} \mathrm{s}^{-1}\right)$

$I_{m}$ : Electrical current (ampere)

L: $\quad$ Ground heat exchanger length (m)

LHV: Lower heating value $(\mathrm{MJ} / \mathrm{kg})$

$P: \quad$ Reference pressure $(\mathrm{kPa})$

$\dot{Q}: \quad$ Heat transfer rate $(\mathrm{kJ})$

$R: \quad$ Heat resistance $\left(\mathrm{kJ} \mathrm{m}^{-1} \mathrm{~s}^{-1} \mathrm{~K}^{-1}\right)$ 
T: $\quad$ Temperature (K)

$\bar{T}$ : $\quad$ Mean temperature $(\mathrm{K})$

$V_{m}$ : Electrical voltage (volt)

$\dot{W}$ : Work rate $(\mathrm{kJ})$

$m$ : Mass (kg)

$\dot{m}:$ Mass flow rate $\left(\mathrm{kg} \mathrm{s}^{-1}\right)$

$n$ : Number of heat exchangers

$t$ : Time (s)

$t_{0}$ : Time of the year's warmest day (hour)

$V:$ Velocity $\left(\mathrm{m} \mathrm{s}^{-1}\right)$

$z$ : Ground depth $(\mathrm{m})$

$\forall$ : Volume $\left(\mathrm{m}^{3}\right)$.

\section{Greek Letters}

$\Phi:$ Exergy $(\mathrm{kJ})$

$\Psi$ : Flow exergy $\left(\mathrm{kJ} \mathrm{kg}^{-1}\right)$

$\alpha$ : Conductivity of soil $\left(\mathrm{m}^{2} \mathrm{~s}^{-1}\right)$

$\pi$ : Global constant

g: Gravity acceleration $\left(\mathrm{m} \mathrm{s}^{-2}\right)$

$\psi$ : Flow exergy $\left(\mathrm{kJ} \mathrm{kg}^{-1}\right)$

$\omega$ : Temperature wave frequency $\left(\mathrm{s}^{-1}\right)$.

\section{Efficiencies}

COP: Coefficient of performance

$\eta_{\mathrm{II}}: \quad$ Exergy efficiency

$\eta_{g, p}:$ Ground pump efficiency

$\eta_{g, x}:$ Ground heat exchanger efficiency

$\eta_{p, 1, c}$ : Evaporator efficiency in cooling mode

$\eta_{p, 2, c}$ : Condenser efficiency in cooling mode

$\eta_{p, 1, h}$ : Evaporator efficiency in heating mode

$\eta_{p, 2, h}$ : Condenser efficiency in heating mode

$\eta_{p, p}:$ Refrigerant pump efficiency

$\eta_{p, v}:$ Expansion valve efficiency

$\eta_{\text {pce }}:$ Power conversion efficiency

$\eta_{s, f}:$ Fan-coil heat exchanger efficiency

$\eta_{s, p}:$ Fan-coil pump efficiency.

\section{Subscripts}

$\begin{array}{ll}0: & \text { Dead state (reference) } \\ \mathrm{CV}: & \text { Control Volume } \\ \mathrm{PV}: & \text { Photovoltaic } \\ c: & \text { Compressor } \\ d: & \text { Design condition } \\ e: & \text { Electrical } \\ g: & \text { Ground } \\ \text { geo: } & \text { Geothermal } \\ i: & \text { Initial condition } \\ \text { in: } & \text { Inlet } \\ \text { load: } & \text { Cooling and heating loads } \\ \text { mean: } & \text { Averaged } \\ \text { out: } & \text { Outlet } \\ \text { tot: } & \text { Total condition } \\ \text { tr: } & \text { Throttling Process } \\ s: & \text { Solar. }\end{array}$

Operators

$d / d t$ : Time derivation

$\sum$ : Summation.

\section{Abbreviations}

EES: Engineering Equation Solver

GSHP: Ground source heat pump

GSHX: Ground source heat exchanger.

\section{Competing Interests}

The authors declare that they have no competing interests.

\section{References}

[1] D. Ürge-Vorsatz, L. F. Cabeza, S. Serrano, C. Barreneche, and K. Petrichenko, "Heating and cooling energy trends and drivers in buildings," Renewable and Sustainable Energy Reviews, vol. 41, pp. 85-98, 2015.

[2] Low Exergy Systems for High-Performance Buildings and Communities, http://www.annex49.info/background.html.

[3] D. Schmidt, "Low exergy systems for high-performance buildings and communities," Energy and Buildings, vol. 41, no. 3, pp. 331-336, 2009.

[4] O. Kwon, K. Bae, and C. Park, "Cooling characteristics of ground source heat pump with heat exchange methods," Renewable Energy, vol. 71, pp. 651-657, 2014.

[5] M. De Carli, S. Fiorenzato, and A. Zarrella, "Performance of heat pumps with direct expansion in vertical ground heat exchangers in heating mode," Energy Conversion and Management, vol. 95, pp. 120-130, 2015.

[6] W. Wu, T. You, B. Wang, W. Shi, and X. Li, "Simulation of a combined heating, cooling and domestic hot water system based on ground source absorption heat pump," Applied Energy, vol. 126, pp. 113-122, 2014.

[7] M. Yari and N. Javani, "Performance assessment of a horizontalcoil geothermal heat pump," International Journal of Energy Research, vol. 31, no. 3, pp. 288-299, 2007.

[8] J. Hirvonen, G. Kayo, S. Cao, A. Hasan, and K. Sirén, “Renewable energy production support schemes for residential-scale solar photovoltaic systems in Nordic conditions," Energy Policy, vol. 79, pp. 72-86, 2015.

[9] A. Martinez-Rubio, F. Sanz-Adan, and J. Santamaria, "Optimal design of photovoltaic energy collectors with mutual shading for pre-existing building roofs," Renewable Energy, vol. 78, pp. 666-678, 2015.

[10] E. K. Akpinar and A. Hepbasli, "A comparative study on exergetic assessment of two ground-source (geothermal) heat pump systems for residential applications," Building and Environment, vol. 42, no. 5, pp. 2004-2013, 2007.

[11] Y. Bi, X. Wang, Y. Liu, H. Zhang, and L. Chen, "Comprehensive exergy analysis of a ground-source heat pump system for both building heating and cooling modes," Applied Energy, vol. 86, no. 12, pp. 2560-2565, 2009.

[12] A. Hepbasli and O. Akdemir, "Energy and exergy analysis of a ground source (geothermal) heat pump system," Energy Conversion and Management, vol. 45, no. 5, pp. 737-753, 2004.

[13] H. Sayyaadi, E. H. Amlashi, and M. Amidpour, "Multi-objective optimization of a vertical ground source heat pump using 
evolutionary algorithm," Energy Conversion and Management, vol. 50, no. 8, pp. 2035-2046, 2009.

[14] L. C. Tagliabue, M. Maistrello, and C. Del Pero, "Solar heating and air-conditioning by GSHP coupled to PV system for a cost effective high energy performance building," Energy Procedia, vol. 30, pp. 683-692, 2012.

[15] M. Bakker, H. A. Zondag, M. J. Elswijk, K. J. Strootman, and M. J. M. Jong, "Performance and costs of a roof-sized $\mathrm{PV} /$ thermal array combined with a ground coupled heat pump," Solar Energy, vol. 78, no. 2, pp. 331-339, 2005.

[16] A. L. Biaou and M. A. Bernier, "Achieving total domestic hot water production with renewable energy," Building and Environment, vol. 43, no. 4, pp. 651-660, 2008.

[17] Q.-Y. Li, Q. Chen, and X. Zhang, "Performance analysis of a rooftop wind solar hybrid heat pump system for buildings," Energy and Buildings, vol. 65, pp. 75-83, 2013.

[18] M. Mikati, M. Santos, and C. Armenta, "Electric grid dependence on the configuration of a small-scale wind and solar power hybrid system," Renewable Energy, vol. 57, pp. 587-593, 2013.

[19] L. Dai, S. Li, L. DuanMu, X. Li, Y. Shang, and M. Dong, "Experimental performance analysis of a solar assisted ground source heat pump system under different heating operation modes," Applied Thermal Engineering, vol. 75, pp. 325-333, 2015.

[20] E. Bertram, "Solar assisted heat pump systems with ground heat exchanger-simulation studies," Energy Procedia, vol. 48, pp. 505-514, 2014.

[21] A. Sahay, V. K. Sethi, A. C. Tiwari, and M. Pandey, "A review of solar photovoltaic panel cooling systems with special reference to Ground coupled central panel cooling system (GC-CPCS)," Renewable and Sustainable Energy Reviews, vol. 42, pp. 306-312, 2015.

[22] F. Sobhnamayan, F. Sarhaddi, M. A. Alavi, S. Farahat, and J. Yazdanpanahi, "Optimization of a solar photovoltaic thermal (PV/T) water collector based on exergy concept," Renewable Energy, vol. 68, pp. 356-365, 2014.

[23] E. Saloux, A. Teyssedou, and M. Sorin, "Analysis of photovoltaic (PV) and photovoltaic/thermal (PV/T) systems using the exergy method," Energy and Buildings, vol. 67, pp. 275-285, 2013.

[24] M. Gholampour, M. Ameri, and M. Sheykh Samani, "Experimental study of performance of Photovoltaic-Thermal Unglazed Transpired Solar Collectors (PV/UTCs): energy, exergy, and electrical-to-thermal rational approaches," Solar Energy, vol. 110, pp. 636-647, 2014.

[25] S. N. Jahromi, A. Vadiee, and M. Yaghoubi, "Exergy and economic evaluation of a commercially available PV/T collector for different climates in Iran," Energy Procedia, vol. 75, pp. 444456, 2015.

[26] A. Bejan, Advanced Engineering Thermodynamics, John Wiley \& Sons, New York, NY, USA, 1988.

[27] K. Wark, Advanced Thermodynamics for Engineers, McGrawHill, New York, NY, USA, 1995.

[28] M. Boxwell, Solar Electricity Handbook: A Simple, Practical Guide to Using Electric Solar Panels and Designing and Installing Photovoltaic Solar PV Systems, Code Green Publishing, 2009.

[29] H. Caliskan, I. Dincer, and A. Hepbasli, "Energy, exergy and sustainability analyses of hybrid renewable energy based hydrogen and electricity production and storage systems: modeling and case study," Applied Thermal Engineering, vol. 61, no. 2, pp. 784798, 2013.
[30] S. Kalogirou, Solar Energy Engineering: Processes and Systems, Academic Press, 2009, http://www.books24x7.com/marc.asp? bookid $=37184$.

[31] J. R. S. Brownson, Solar Energy Conversion Systems, 2014, http:// public.eblib.com/choice/publicfullrecord.aspx? $\mathrm{p}=1562328$.

[32] C. Koroneos and M. Tsarouhis, "Exergy analysis and life cycle assessment of solar heating and cooling systems in the building environment," Journal of Cleaner Production, vol. 32, pp. 52-60, 2012.

[33] Carbon Dioxide Emission, http://www.engineeringtoolbox.com/ co2-emission-fuels-d_1085.html. 


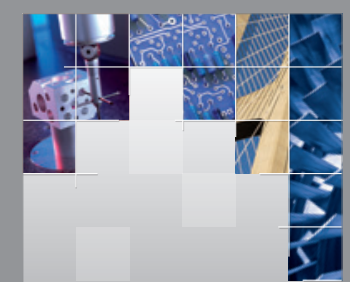

\section{Enfincering}
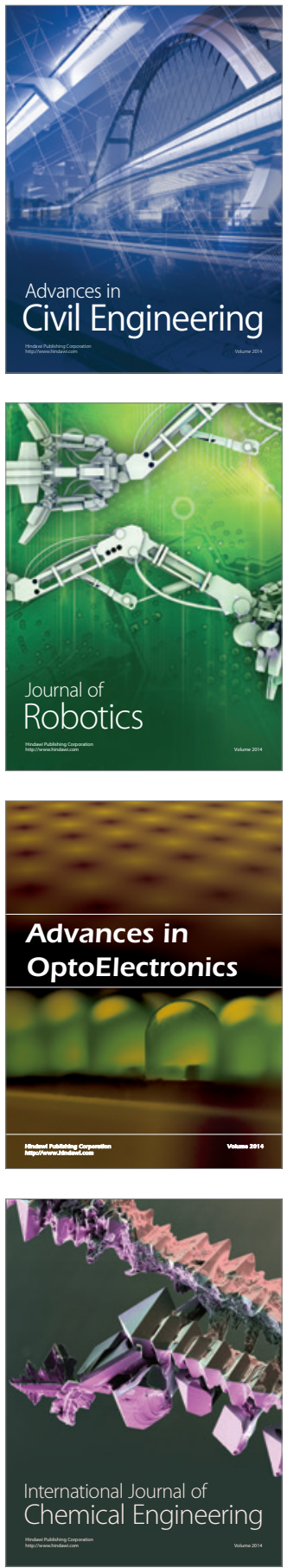

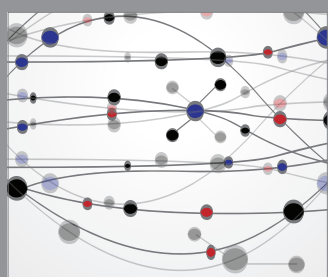

The Scientific World Journal

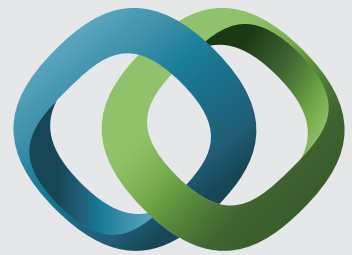

\section{Hindawi}

Submit your manuscripts at

http://www.hindawi.com
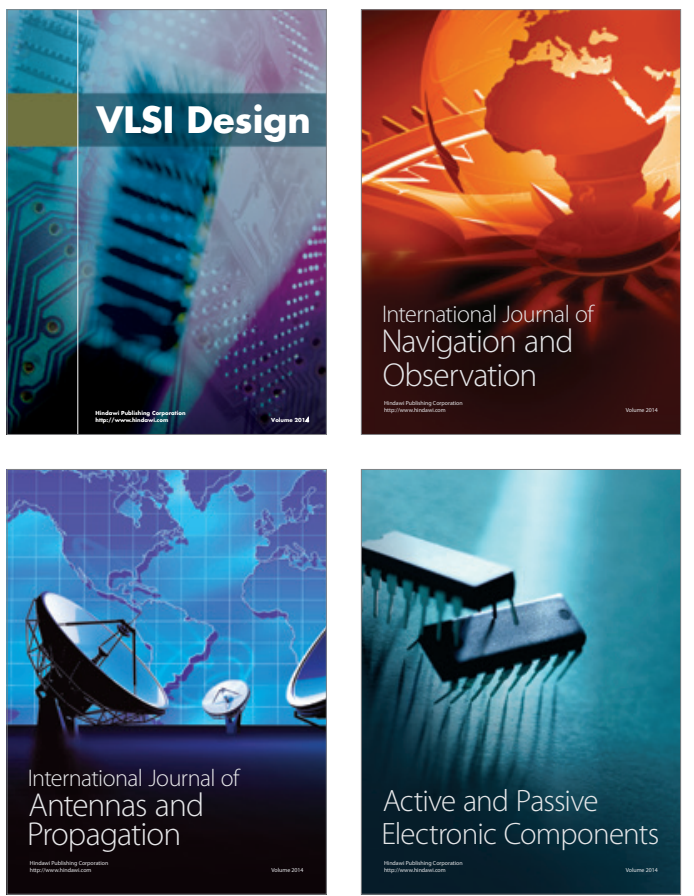
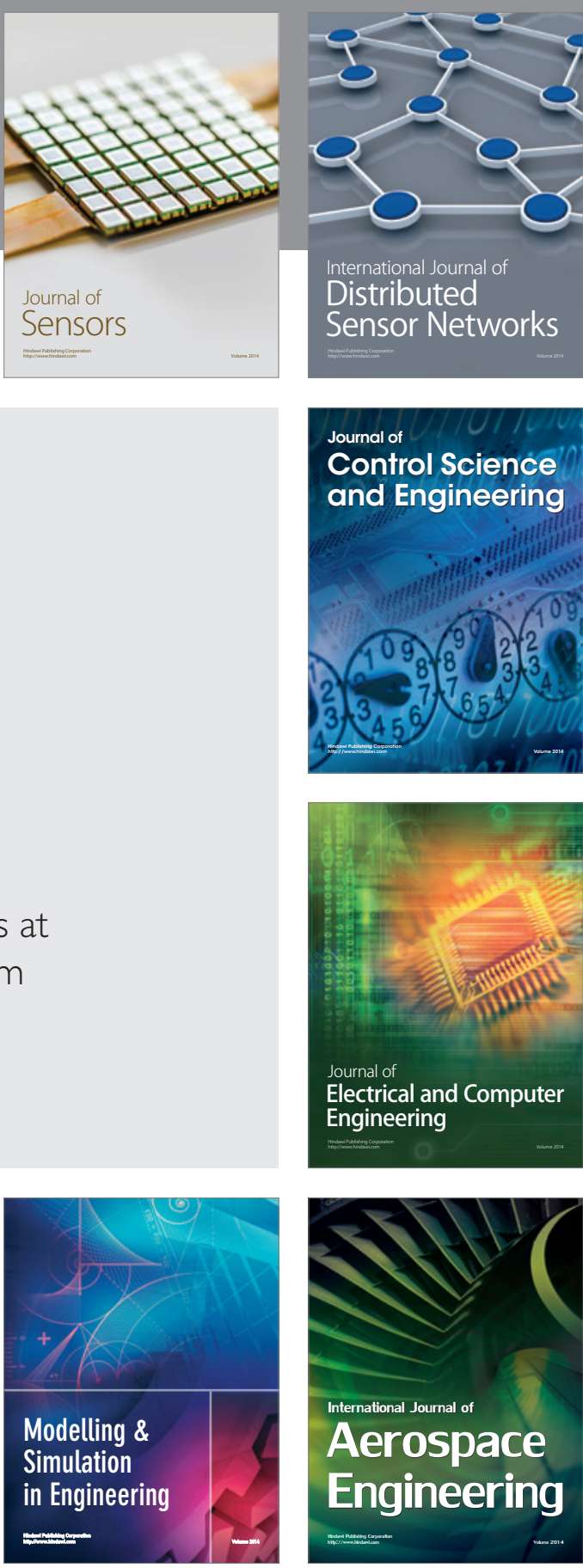

International Journal of

Distributed

Sensor Networks

Journal of

Control Science

and Engineering
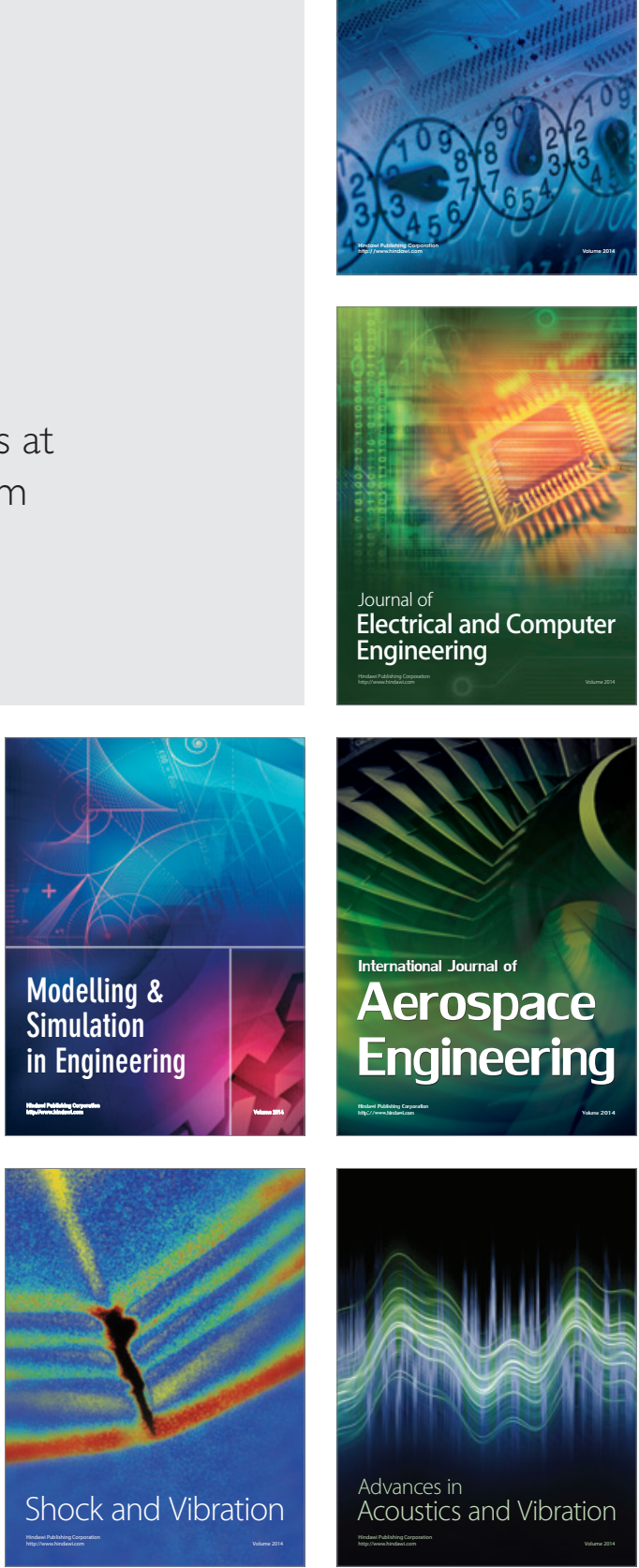